\title{
Theory and Practice of Delegation to Non-Majoritarian Institutions
}

\author{
MARK THATCHER and ALEC STONE SWEET
}

A transformation in governance has swept across Western Europe. During the past half-century, states, executives, and parliaments have empowered an increasing number of non-majoritarian institutions (NMIs) ${ }^{1}$ to make public policy. In the fields of utility regulation, telecommunications, antitrust, and media pluralism, and even in the provision of health and welfare benefits, myriad independent regulatory bodies have been created and become the loci for making new rules, or applying existing ones to new situations, at the national level. At the supranational level, central bankers, insulated from direct political control, set monetary policy. In Brussels, European Commission officials propose legislation and enforce ever wider European Union regulation. In Luxembourg, the Court of Justice controls member state compliance with European law, reviewing the lawfulness of activities of national parliaments, governments, and administrators.

The ongoing exercise of authority by non-majoritarian bodies is today central to governance in a growing number of policy domains. This special issue seeks to address the sources, consequences, and dynamics of delegation to NMIs in Western Europe. Here we introduce the core themes and issues raised by the project, while each subsequent article explores the politics of delegation more specifically in different polities, sectors, and institutional settings. We begin by discussing how the group has collectively chosen to define and conceptualise our topic; we then present theoretical materials used by political scientists to explain delegation to nonmajoritarian institutions. These ideas developed in the United States during the 1980s, primarily in research on the relationship between Congress and American regulatory agencies (see Pollack, this volume). ${ }^{2}$ We also briefly discuss relevant ideas found in 'new-institutional' organisational sociology. ${ }^{3}$ Following from the seminal work of Giandomenico Majone ${ }^{4}$ and Mark Pollack, ${ }^{5}$ a literature that uses or otherwise engages American delegation theory to conceptualise or explain aspects of supranational politics in the EU has emerged, and is becoming a standard reference point. ${ }^{6}$ Nonetheless, comparative research on the sources and consequences of institutional innovation through delegation to NMIs has been, until recently, scarce. ${ }^{7}$ 
Thereafter, we examine the politics of delegation to NMIs in Europe the decision to delegate, the institutional design of delegation and the consequences of delegation- in light of the project's findings.

\section{CONCEPTS AND THEORY}

The title of this volume, The Politics of Delegation: Non-Majoritarian Institutions in Europe, would seem to be relatively self-explanatory, yet commonplace words do not always mean the same things to different people. Our project is concerned with politics, by which we mean public governance. Although explicit acts of delegation can constitute private systems of governance (for example, those of the modern corporation), and although private domains are full of politics, we have chosen to limit our focus to delegation through public authority. We nonetheless conceive of governance in a broad, generic way. By governance, we mean the processes through which the rule systems in place in any human community are adapted, on an ongoing basis, to the needs and purposes of those who live under them. ${ }^{8}$ When governments draft legislative bills, and when legislators debate, amend, and adopt statutes, they act to (re)construct legal regimes, and thereby to govern. When administrative officials, operating under a grant of statutory authority, interpret in order to apply the law in concrete situations, they too govern. Of course, in a very important sense, all public governance operates by way of delegation in Europe. The standard model of parliamentary democracy, for example, has it that (a) the (sovereign) people bestow authority on legislators by elections, (b) ministers derive their collective powers from parliament, and (c) the extent of an administrator's discretion is determined by statute, as controlled by courts. In liberal democratic theory, explicit acts of delegation legitimise the exercise of public authority.

We have chosen to narrow our focus further, to non-majoritarian institutions, which we define as those governmental entities that (a) possess and exercise some grant of specialised public authority, separate from that of other institutions, but (b) are neither directly elected by the people, nor directly managed by elected officials. We exclude from consideration state powers organised within the bureaucracy, when the exercise of such powers are placed under the direct control of ministers and the civil service. We do not exclude a specialised organ or agency that may be linked to a ministry in certain formal ways, so long as that body is not merely a department or administrative office of a larger bureaucratic entity. As this volume shows, such institutions take a wide diversity of structural forms in Europe, including independent regulatory agencies, specialised courts, standardsetting boards, central banks, the European Commission, and so on. 
Given our substantive concerns, we define delegation as an authoritative decision, formalised as a matter of public law, that (a) transfers policy making authority away from established, representative organs (those that are directly elected, or are managed directly by elected politicians), to (b) a non-majoritarian institution, whether public or private.

\section{The Principal-Agent Approach}

The 'Principal-Agent' ( $\mathrm{P}-\mathrm{A})$ framework, developed in American political science from materials found in organisational and 'transaction cost' economics, ${ }^{9}$ dominates research on the topic of delegation to nonmajoritarian institutions. (Although different terms are sometimes used in the various strains of this research, we ignore these distinctions here, focusing on the main elements of P-A approaches; moreover, because Mark Pollack's contribution to this volume, among other things, surveys the development of the $\mathrm{P}-\mathrm{A}$ approach in research on American politics, we discuss only the basics here.) In some respects, this dominance is hardly surprising, since the framework was explicitly developed to account for delegation. The framework has proved popular, not least because it offers the analyst readymade, appropriate concepts, and focuses attention on some of the important empirical questions about which most political scientists interested in the topic are likely to be concerned. That said, the $\mathrm{P}-\mathrm{A}$ framework as it presently exists is just that - a framework. As causal theory - that is, as an integrated body of concepts, operationalisable variables, and testable propositions - it remains incomplete. Indeed, as two proponents of the approach have recently noted, 'scholars are only beginning to scratch the surface of what needs to be done to establish the theoretical validity of the transaction cost approach'.10 Further, hypotheses generated from interpretive case studies and formal models of delegation have not always found support in subsequent research designed to test them. ${ }^{11}$

It is our view that the $\mathrm{P}-\mathrm{A}$ construct, a general, relatively flexible, and established approach to thinking about delegation, could not be ignored in research on NMIs in Europe. The directors of this project did not impose (for example, by requiring the adoption of) $\mathrm{P}-\mathrm{A}$ analysis on contributors. Instead, we asked those critical of the approach to indicate to our readers the source of their objections. Further, some contributors sought explicitly to supplement, or replace, $\mathrm{P}-\mathrm{A}$ ideas with concepts found in other approaches. ${ }^{12}$ In all cases, we agreed that important empirical aspects of the politics delegation should be prioritised, not just theory.

\section{Functional Logics of Delegation}

For our purposes, principals are those political officials who use their authority to establish non-majoritarian institutions through a public act of 
delegation. Agents are those who govern by exercising delegated powers. By assumption, principals are initially in control, in the strict sense that the precise terms of the agent's remit are a matter of institutional design, and the authority to constitute or not to constitute agents falls within the principals' jurisdiction. Because principals are willing to pay the costs of delegation (for example, time and deployment of resources to establish the new institution and to monitor its activities), they must have found it in their interest to do so. Indeed, it must be that the expected benefits of delegation outweigh the costs. Put simply, delegation is functional for principals.

One can be more specific. The more common rationales for delegation from legislators to agencies, and from nation states to international organisations, are well known. Principals constitute agents to help them:

- resolve commitment problems (agents are expected to work to enhance the credibility of promises made, either between multiple principals, or vis-à-vis principals and their constituents, given underlying collective action problems);

- overcome information asymmetries in technical areas of governance (agents are expected to develop and employ expertise in order to produce, or help principals produce appropriate public policy);

- enhance the efficiency of rule making (agents are expected to respond to relatively specific problems and issues that arise, while principals set and then update the more general terms of policy);

- avoid taking blame for unpopular policies (agents are expected to maximise policy goals that principals know may sometimes be unpopular with important societal groups).

Of course, for any specific act of delegation, these and other rationales may overlap, or be one and the same.

Principals can realise the benefits of delegation only by granting discretion to the agent, that is, through sharing some of their authority to govern. We will define discretion more carefully shortly. For now, let us agree that principals know that agents are likely to develop their own interests - including an interest in producing the best policies, given their own understanding of the nature of the policy problem and the environment - and that these interests may conflict with those of the principals. Simplifying, the extent to which an agent actually does generate outcomes that are 'different from the policies preferred by those who [have] delegated power', ${ }^{13}$ is registered as an 'agency loss'. Principals can reduce agency losses in advance by conferring restrictive powers on the agent, or on an ongoing basis by monitoring and reining in the agent. Institutional design is 
an exercise in choosing from a menu of both ex ante and ex post (that is, ongoing) controls. ${ }^{14}$ Yet, because the benefits of delegation decline the more the principal limits the agent's discretion, the trick is to delegate just the amount of power to enable agents to achieve desired outcomes with minimal agency loss. After all, legislators and member states are not required to delegate; they could govern, through statutory, administrative, and judicial means, without creating new agents.

Contributors to this volume were asked to confront questions of institutional design. Why, and on what terms, do relevant acts of delegation occur? What systems of oversight are constructed to monitor the activities of agents? Through what mechanisms can decisions taken by agents be quashed?

\section{Agency Discretion and Control}

In the American literature the question of how best to define and operationalise the gap that (inevitably) develops between what principals want from agents and what agents actually do remains an open one. Underlying the debate are differing views of the nature of discretion. In this volume, we conceive of this gap in terms of a theoretical 'zone of discretion'. This zone is constituted by (a) the sum of delegated powers (policy discretion) granted by the principal to the agent, minus (b) the sum of control instruments, available for use by the principals to shape (constrain) or annul (reverse) policy outcomes that emerge as a result of the agent's performance of set tasks. The zone of discretion can be defined without reference to the policy preferences of the principal or the agent, as we have just done. But for a number of reasons we expect such preferences to be fundamental to the dynamics of the relationship between discretion and control.

First, if principals create an agent in order to realise certain policy objectives, then the distribution of policy preferences among them, at the $e x$ ante moment of delegation, will help to determine how the zone of discretion will be constructed. If principals wish to commit their successors to the goal of low inflation, for example, they may decide to create a central bank that is more or less insulated from interference by future elected officials. If, faced with high levels of uncertainty in a given domain, they hope to perfect the terms of regulatory policy - as problems emerge and evolve - they may seek to construct effective ex post controls over their agent. If they desire the smooth implementation of product standards, they may require that the agent consult with those who are being regulated. Thus, functional logics can generate relatively straightforward and testable propositions. The more principals seek to pre-commit themselves to specific policy outcomes, for example, the more powers they will delegate to an 
agent, and the weaker will be ex post mechanisms of control. In contrast, the more principals seek a rich range of policy alternatives from which to select, on an ongoing basis, the stronger will be the ex post mechanisms of control. Our point is not that there is one functional logic of delegation, but diverse ones, and that this diversity is partly generated by the preferences and objectives of principals at the moment of constituting the agent.

Second, once an agent begins to exercise decision making powers, the extent to which ex post instruments of control will actually be activated will be partly related to the principal's preferences over outcomes. The smaller the zone of discretion, the greater the agent's interest will be in monitoring and anticipating the principal's reactions to activities, to the extent of the fear, or wish to avoid, having decisions overturned.

Third, in many situations, principals are not unified, which increases the complexity of dealing with changes in preferences. Composite principals that is, a principal comprised of multiple actors whose collective makeup changes periodically through, for example, elections - may not possess stable, coherent preferences over time. Instead, they may be competitive with one another over some or many issues, as when member state governments in the EU disagree on matters of policy that fall within the agents' mandate. Even more complicated, the initial act of delegation may parcel out - among multiple actors - the functions normally associated with that of the principal. One organ may possess the power to quash a decision taken by the agent, while another has staffing and funding authority. In such cases, the linkages between the principals' policy preferences, the agent's performance, and the principals' capacity to control the agent may be diluted. In the EU, for example, the Court of Justice, the Court of First Instance, and the EU legislator (the Council of Ministers and the EP), have powers to nullify the prospective effects of certain Commission acts taken pursuant to secondary legislation, powers that depend on legal basis and other circumstances. However, when the Commission enforces competition rules, only the EU courts and those entities empowered to revise the treaty may reverse its decisions. Is the Court of Justice a principal when it quashes a Commission decision, or revises a Treaty provision through constitutional interpretation in ways that bind the member states? No, since the founders of the treaty designed the Court as an agent whose tasks include monitoring the activities of other agents, and of the member states themselves. Control over the Commission's purse strings is mostly supranational, while control over its recruitment is mostly intergovernmental; the EP can dismiss the Commission on its own if it so decides. In situations of this complexity, the analyst cannot assume that principals can control agents; instead, the relationship between principals and agents must be carefully stipulated, in light of the various means of control at the disposal of the former. 
Finally, institutional arrangements - for example, the relative sizes of 'zone of discretions' - are continuous variables that organise principalagent relations. Majone has forcefully argued ${ }^{15}$ that when 'political property rights' ${ }^{16}$ have been transferred to agents, more or less completely and in permanence, the standard P-A framework loses much of its relevance and utility. Some members of this group agree (for example, Stone Sweet, this volume). Majone proposes a model of fiduciary relations, in which principals, faced with acute commitment problems, delegate broad, openended authority to trustees to govern in their stead. In Majone's terms: 'Trustees are agents, but not all agents are trustees; a trustee is an agent and something more'. ${ }^{17}$ A trustee typically wields the power to govern those who have delegated in the first place. In the EU, for example, one of the Court's tasks is to interpret authoritatively provisions of the Treaty of Rome; such rulings govern all legal persons in the Community, including the member states. The Court, as constitutional court, ${ }^{18}$ is a trustee that is well insulated from formal controls. However, when the Court interprets a regulation or directive, it acts more as the agent of the EU legislator, and the EU legislator monitors and corrects the Court's rulings, through subsequent legislative acts, as the legislator see fit. ${ }^{19}$ Similarly, as Majone points out, when the Commission enforces competition rules it acts as a trustee (the competence is stipulated by the Treaty); when it applies secondary legislation to situations, it acts more as an agent. One proposition that can be derived from such distinctions is that in a trustee situation, that is, where the zone of discretion is all but unlimited, temporal changes in the distribution of the principals' preferences will have less impact on the agent's activities, or policy outcomes, than in an agency situation. The problem of knowing how to identify the exact point, along any given spectrum that arrays various forms of delegation, the agent is more properly theorised as a trustee has not been resolved.

\section{Alternatives to Principal-Agent Logics}

This project did not seek to achieve intra-group consensus on methods or theory, but rather to initiate debates about both, in light of our respective empirical interests. Indeed, one of this volume's objectives is to assess alternatives to $\mathrm{P}-\mathrm{A}$ approaches to delegation. Let us clear away one false issue immediately. We see no point in seeking to 'disprove' the P-A construct, which is a vocabulary and a body of concepts, any more than one could 'disprove' rational choice approaches to politics more generally. There is a long tradition, both inside and outside the parameters set by the framework, of criticising existing applications of the framework for having been poorly specified. ${ }^{20}$ Faced with a challenge to received wisdom, the $\mathrm{P}-\mathrm{A}$ framework, like most rational choice-based theorising, is almost always 
flexible enough to absorb new variables and logics, albeit through respecifying concepts in its own peculiar language.

That said, purely functional analysis is incapable of explaining some important aspects of the emergence and evolution of institutional arrangements. Stipulating the existence of sufficient functional demand to support and sustain a new non-majoritarian institution tells us next to nothing about how actors came to define problems in ways that pointed to delegation. Functional problems can be addressed in myriad ways. How actors perceive, and then select from, the choices available to them is almost always conditioned by local histories, pre-existing institutional arrangements, and contingent forces and events. Further, assuming that a specific institution does provide some of the benefits of delegation tells us nothing about how agents actually perform, and with what effect on the world. Generally, functional analyses alone are ill-suited to deal with the temporal dynamics of delegation.

The P-A framework may be dominated by other approaches on these and other dimensions as well. So-called sociological institutionalists, for example, have explored the question of why some forms spread as quickly as they do, across social systems, at one time in history, rather than others. ${ }^{21}$ Historical accounts of 'institutional isomorphism' - how organisational forms and models develop, standardise, and diffuse ${ }^{22}-$ are typically more causally complete than are functional accounts. Although P-A approaches focus heavily on institutional choice through design, organisational sociologists have been more concerned with the broader processes that advantage some institutional arrangements while disadvantaging others. Further, unlike theories that are specified more generally, standard P-A models operate at very low levels of abstraction, and do not in themselves travel well. After all, a properly specified model purports to represent the particularities of a specific case. Last, $\mathrm{P}-\mathrm{A}$ approaches have been slow to develop tools to capture the dynamics of the relationship between principals, agents, and society, relationships typically constructed over time by complex feedback loops that are difficult to model rigorously in gametheoretic ways. So-called historical institutionalists claim to have developed better tools, and they may be right. We return to these and related topics in the next section.

Depending upon the research question, there may be comparative advantages to using an existing alternative. For some purposes, a P-A analysis might profitably complement a sociological or historical approach, or one may help to explain residual variance left over by the other. But it also may be that explanatory approaches developed by sociologists and organisational theorists simply perform better, across the board, than do $\mathrm{P}-\mathrm{A}$ approaches. There are fierce difficulties associated with adjudicating 
between theories that may be a priori incommensurate. In this project, we encouraged contributors to explore these issues as fully as possible, in terms of more specific empirical concerns.

\section{DELEGATING TO NON-MAJORITARIAN INSTITUTIONS IN EUROPE}

At first sight, the idea of elected politicians voluntarily passing powers to unelected bodies such as courts, regulators, independent central banks and the European Commission and Court of Justice runs counter to post-war experiences of expansion in state activities and competencies in Western Europe. Not surprisingly, our studies show that elected officials in Europe have delegated in order to resolve various collective action problems. National governments have transferred powers to EU institutions in order to deal with the negative externalities of market integration, as well as to monitor and enforce EU law (Tallberg, this volume). Constitutional courts have provided a response to the dilemma of political parties who agreed on the benefits of constitutional 'rules of the game', but disagreed, sometimes fundamentally, on the precise content of those rules (Stone Sweet, this volume). Independent regulatory authorities (Thatcher, this volume) and competition authorities (Wilks and Bartle, this volume) have responded to pressures to stabilise environments for investors, while enabling the state to respond more effectively to increased technical complexity. ${ }^{23}$ The rhetoric justifying independent central banks (McNamara, this volume) emphasises the advantages of low inflation and price stability, thus reassuring key business and financial interests. All of these bodies may offer elected politicians scapegoats for hard choices for which they might otherwise be blamed.

While functional demands for delegation can almost always be identified, most of the contributors to this volume argue that the pressures on elected officials and the functions that NMIs can perform for them do not, alone, explain the expansion of NMIs in Europe. Several lines of attack are developed against purely functionalist models. First, those who delegate are not just responding to functional demands; instead the perception that delegation to NMIs is the best option for dealing with certain problems is socially constructed, and that process is always analytically prior to the decision to delegate. Katherine McNamara (this volume) denies that independent central banks are a natural or necessary response to resolve a commitment problem. She shows that independent central banks do not always produce lower inflation and higher growth, that higher inflation does not always harm economic growth, and that partisan-electoral factors do not always lead to higher rates of inflation. Indeed, central bank independence was introduced in Western Europe in the 1990s in an era of very low 
inflation. Instead, what is crucial is that elected officials around the globe have come to see the independent central bank as an institution that fits better with more general ideas about how the economy works than does a bank controlled directly by a national treasury. In the field of competition policy, Stephen Wilks and Ian Bartle (this volume) argue that the creation of competition authorities in Britain was initially symbolic. Governments wished to reassure business whilst believing that the authorities would be unimportant (although in fact, those expectations were not fulfilled).

A second set of challenges for functionalist explanations arises from variation, whether read across nation-states or policy domains. Most $\mathrm{P}-\mathrm{A}$ work on delegation has not attempted much cross-national comparison, although Western Europe offers a fertile ground for developing and testing theory. ${ }^{24}$ European polities, partly because they are similarly developed and integrated into international and regional economies, face similar functional pressures for delegation to NMIs. Yet outcomes vary. Although delegation to NMIs has spread, countries have made quite different choices over when, whether and how to delegate. Thus, Mark Thatcher (this volume) shows that the practice of delegating to national independent regulatory agencies has diffused steadily across various policy sectors, but that the structure and operation of these agencies varies widely within any given domain, despite the existence of similar pressures. There is also important variation across sectors, within countries. Marian Döhler (this volume), for instance, finds that Germany has delegated relatively little beyond long-standing, successful NMIs, such as the Bundesbank, the Federal Cartel Office, and the Constitutional Court.

Third, functionalist explanations cannot account for the timing of delegation. Germany established at least a semi-independent central bank and a national competition authority in the 1950 s, while other countries only did so in the late 1980s and 1990s. The date of creation of constitutional courts and independent regulatory agencies for the utilities also differs across countries. Many of the governance problems emphasised by proponents of $\mathrm{P}-\mathrm{A}$ approaches pre-date delegation, credible commitment in monetary policy or regulation, technical complexity or unpopular policies. Yet they were rarely met by delegation to NMIs before the 1980s and 1990s.

Two sets of responses to these problems emerged within our group. One was to adapt the $\mathrm{P}-\mathrm{A}$ approach to the politics of NMIs in Europe by carefully specifying local conditions. In the European context, which, in contrast to the US situation, features strong political parties and parliamentary government, the principals are mostly governments and political parties. Although parliaments may pass legislation to delegate powers to NMIs, they are largely controlled by the executive through strong party systems and constitutional constraints. Contributors then investigate 
how and why governments and parties delegate, in the context of new or inherited political and constitutional structures. Several of the articles in this volume (Stone Sweet, Tallberg, and Pollack, this volume) proceed in this way. Others in the group felt that the P-A framework was too limiting, and not sensitive enough to the contingencies of history, agency, ideas, and so on (Döhler, Thatcher, Wilks and Bartle). They wanted richer accounts of why, when, and how delegation occurs, and they explore factors that $\mathrm{P}-\mathrm{A}$ analyses conceptualise differently, mention only in passing, or ignore altogether. We discuss three of these factors here: the definition of interests, institutional isomorphism, and historical legacies. These are applied to the two key elements of institutional design: the decision to delegate; and the institutional form selected.

\section{The Decision to Delegate to an NMI}

Since delegation is not costless, principals must believe that their interests are better served by delegating to an NMI, relative to an existing situation or an alternative institutional arrangement. Their decisions are influenced by national and international examples of delegation, by pressures from those to be regulated or otherwise concerned, and by existing institutional constraints. Hence we need to investigate the interests of decision makers, policy learning and institutional isomorphism, and institutional inheritances.

Interests. Offering a fuller explanation of the spread of delegation of NMIs (including variations in extent and timing), whether within a $\mathrm{P}-\mathrm{A}$ framework or outside it, must begin by specifying the interests of the key actors involved in the decision to delegate. The question of how, across Europe, delegation to NMIs came to be considered an appropriate response to an increasing number of governance problems is an empirical one; it must be investigated rather than assumed or traced backwards from the existence or lack of delegation. Some members of the group addressed this question through methods commonly associated with 'historical' and 'sociological' institutionalism, ${ }^{25}$ showing how preferences for new NMIs were constructed or altered (for example, McNamara, Thatcher, Wilks/Bartle, this volume). They show several routes whereby the interests of elected officials altered. Pressures were exerted on governments by powerful interests such as bankers and business, who sought delegation for their own ends, such as a more predictable, less 'politicised' environment. Assumptions of how agreed policy aims could be achieved evolved - for example, politicians came to believe that their interests in low inflation were better served by an independent central banks. In fields such as general competition policy or sectoral regulation, elected officials, confronted by scandals, technical complexity and international pressures, together with new ideas and 
examples for reform, concluded that having direct control over policy, or at least appearing to have it, was no longer advantageous.

Other contributors adopted standard assumptions of rational choice (for example, Shapiro, Stone Sweet, Tallberg, this volume), but then focused attention on how the activities of agents within domains constituted by delegation 'feeds back' onto the wider political system. Thus judges, be they in constitutional courts or engaged in judicial review, have developed legal doctrines that extend their powers and constrain those of elected politicians. In the EU, the ECJ exploited differences among national governments to enhance the effectiveness of EU law, and thus to increase its owns powers in the polity.

Policy Learning and Institutional Isomorphism. Policy learning and institutional isomorphism (transfer of institutional forms) have been crucial to the spread of NMIs in Europe. ${ }^{26}$ At times, the American experience with delegation has generated templates for reform and norms of appropriateness that have travelled across the Atlantic, particularly to Britain. ${ }^{27}$ In other situations, European polities have copied one another. General competition authorities spread via an 'orgy of borrowing' (Wilks and Bartle, this volume); the creation of an independent regulator in telecommunications in Britain was followed by similar bodies in other European countries (Thatcher, this volume); the Austrian constitutional court ultimately mutated into a pan-European institution, through successive waves of democratisation in this century (Stone Sweet, this volume); independent central banks (McNamara, this volume) became de rigueur in the 1990s. ${ }^{28}$ Cross-domain isomorphism has probably been less important, although it has taken place across closely related fields, such as utilities regulation. ${ }^{29}$

Much of the day-to-day politics in domains governed by NMIs is heavily structured by the activities of knowledge-based elites. These include scientists, other technical experts, economists, bankers, and lawyers. Such actors have developed strong corporate or professional interests in the work of NMIs. They help to diffuse NMIs and the models of governance that go with them facilitate institutional isomorphism, not least by working to legitimise some forms of governance while delegitimising others. ${ }^{30}$ In increasingly Europeanised and internationalised domains such as central banking, utilities regulation or competition policy, transnational communities of professionals have contributed to making delegation to NMIs part of 'good governance' norms that have become orthodoxy. ${ }^{31}$ The process has not been disinterested: these actors increase their own social power and influence.

'Coercive isomorphism' ${ }^{32}$ - the diffusion of institutional forms and practices through legal obligation backed up by monitoring and 
enforcement mechanisms - has also played a role in the spread of delegation to NMIs. European integration has favored isomorphic processes. ${ }^{33}$ The Maastricht Treaty, for example, insisted on independent central banks as a precondition for entry into a single currency. Many important pieces of EC secondary legislation provide pressure for delegation to specialised agencies. New constitutions, the European Convention of Human Rights, and the development of EU law require judges to engage in more judicial review of agencies (Shapiro, this volume).

Institutional Legacies. The pace and scope of delegation to NMIs have been strongly mediated by national-level factors. ${ }^{34}$ State structures influence the possibility, attractiveness, and ease of delegation to NMIs. In countries such as Britain, with relatively few constraints on the executive and no entrenched constitution, delegation to NMIs can be achieved relatively quickly. Thus the Bank of England was made independent in 1997, almost literally overnight, despite no such pledge having been made in Labour's election manifesto. When constitutions have broken down and are completely rewritten, powerful opportunities exist for delegation - for instance, by creating new constitutional courts or agencies. However, if the creation of a new NMI requires constitutional amendment, with supermajorities or special procedures, reforms will be more difficult to introduce. Delegation in Germany faces an uphill battle to the extent that it meets with various legal obstacles, such as the constitutionally protected prerogatives of the Länder (see Döhler, this volume).

State structures and institutional legacies affect the relative costs and benefits of different organisational forms. ${ }^{35}$ In Britain, regulatory commissions date back to the nineteenth century. Moreover, governments find it relatively easy to alter the organisational basis and personnel of NMIs such as regulatory agencies which do not enjoy specific constitutional protection. In countries like Italy, such agencies have formal independence and nomination procedures can be complex due to the involvement of the legislature. In Germany, an alternative and apparently successful regulatory model of federal agencies within ministries, a powerful Cartel Office and strong regional traditions, have acted as a barrier to the creation of sectoral independent regulatory agencies. ${ }^{36}$ Inheritance also affects learning and the search for organisational forms. Thus, long-standing linkages by British policy makers to the United States aided the importation of American examples of delegation; one example is the way in which utility commissions such as the FCC in telecommunications, inspired semiindependent regulators in Britain. ${ }^{37}$ In contrast, continental states have looked more to each other for institutional developments. 
Institutional Forms of Delegation to NMIs

Delegation to non-majoritarian institutions has taken many forms in Europe, both cross-nationally and across domains. Comparison of 'zones of discretion', requiring examination of the powers delegated and the controls imposed on NMIs, offers insights into the variety of institutional forms.

Constitutional courts and independent central banks operate in the most extensive zones of discretion, although there is significant variation across countries. Their decisions are difficult to reverse, often requiring constitutional amendment, they face relatively few ongoing controls and their organisational position is frequently highly protected by being embedded in constitutions. The European Commission operates in a more restrictive environment when it deals with representatives of the memberstates in the Council of Ministers or the European Council, than it does when it enforces the competition rules found in the Rome Treaty. In Majone's terms, in the former context it looks and behaves like an agent vis$\grave{a}$-vis principals, while in the latter it resembles, as does the constitutional judge, a trustee exercising fiduciary powers (Stone Sweet, Tallberg, this volume).

The sum of powers delegated to national regulatory authorities looks modest when compared to the courts and central banks. Regulators' powers are circumscribed - for instance, to policing specified anti-competitive behaviour, approving certain types of merger, imposing fines and enforcing licences. Their decisions can be reversed relatively easily - by ordinary legislation, judicial ruling, or sometimes simply by ministerial order. They require considerable resources to function effectively, but these are allocated by annual budgetary procedures under the control of their principals, namely governments and legislatures. Legally, elected officials can easily abolish or alter the organisational structure of regulatory authorities since these are rarely protected by constitutional provisions. The volume, nonetheless, shows that the authority of these agents has increased over time. Finally, delegation has been weakest towards executive agencies of governments (see Döhler, this volume). Indeed, most were excluded from this volume because they did not meet the minimum requirements to constitute a NMI, particularly that of not being directly managed by elected officials and enjoying powers separate from other institutions, notably ministers and civil servants.

One explanation of differing forms across domains is to link institutional design to pressures on principals and the functions performed by NMIs offers. Where delegation takes place in order to secure credible commitment, principals cannot impose many ex post controls over the agent without undermining the very purpose of delegation. The more acute the commitment problem that principals face (or believe they face), the more 
discretion they will delegate - for example, in enforcing EU law or in monetary policy. Where officials delegate to increase technical efficiency, reduce their workload, or improve their information, extensive ex post controls are often more compatible with objectives. Thus, when principals seek to take advantage of the technical expertise of NMIs in regulatory environments characterised by great uncertainty, they will create agents (and not trustees) whose purpose is to lower the costs of making good policy.

Such general functionalist explanations of institutional form are useful but equally are subject to the same criticisms as those applied to analyses of the decision to delegate. They offer only limited predictions about specific choices made in countries or domains that are strongly influenced by history and context. Choices over institutional form are often greatly constrained by cognitive and normative limits, existing state structures, and institutional legacies. Hence contributors enriched their explanations by looking at such factors either within a P-A framework or outside it.

State and domain traditions provide templates of institutional forms. Often elected officials copy existing forms, leading to 'institutional isomorphism'. In Germany, the same 'genetic code' has led to an almost automatic copying of the same institutional form for federal agencies (Döhler, this volume). Institutional forms have been 'read across' domains within countries for regulatory agencies, leading to a 'British utility regulatory' model, or French 'Autorités Administratives Indépendentes' (Thatcher, this volume). The spread of the Kelsenian constitutional court, now in place from Portugal to Russia, proceeded first from the rejection of American-style judicial review, given embedded separation of powers doctrines, and then through rote copying (Stone Sweet, this volume).

Constitutional and state arrangements strongly structure decisions on institutional form. In countries with legislatures that enjoy greater independence from the executive, nomination to, and controls over, agents tend to be shared between the two bodies (for example, Germany, Italy). Where executive powers are more highly centralised (Britain, France), such controls are typically wielded by cabinets and ministries. ${ }^{38}$ The extent of judicial review of agencies and its biases towards support for agencies or for challengers to them, are influenced by factors such as national legal doctrines, legal fashions, and the training, recruitment and career patterns of judges (Shapiro, this volume).

\section{POLITICAL DYNAMICS AND CONSEQUENCES}

The consequences of delegation to NMIs are as important as decisions over initial institutional design for our case studies. NMIs have become powerful 
participants in policy making and may now constitute a 'fourth branch of government' in Europe. Delegation to them has affected the distribution of power, with winners and losers. It has also had impacts on processes of decision making, substantive policy making and further institutional reform. For analytic purposes, we can divide the effects of delegation to NMIs into two groups: the immediate and direct effects of NMI behaviour; feedback effects whereby NMI decisions affect the wider environment of NMIs leading to further rounds of consequences. In addition, delegation to NMIs has raised wider concerns of legitimacy and accountability.

The case studies suggest that the greater the initial 'zone of discretion', the more significant are the effects (direct and indirect) of delegation and the more likely are unanticipated consequences. NMIs such as constitutional courts, which have great powers and face few controls (that is, are better understood as trustees than agents), routinely generate sweeping outcomes that are frequently unanticipated. Nevertheless, understanding the consequences of delegation requires tracing the effects of NMI behaviour in their context and inclusion of the reactions of other actors: the formal initial zone of discretion is the starting point for analysis, not the end of it.

\section{Direct Effects}

Within the state, delegation has seen the emergence of powerful NMIs. Analysts using P-A approaches typically focus on the extent to which agents may escape from the latter's control, due to information asymmetries, divided or multiple principals, and so on. They then discuss how the design of formal controls can limit such 'agency losses' ${ }^{39}$ Yet determining 'agency losses' and 'control' poses fierce methodological difficulties, especially of observed equivalence, as Mark Pollack points out. We have therefore examined the relationship between elected officials and NMIs in relation to the initial 'zone of discretion' established by formal powers and controls. As a result, case studies are sensitive to how the position of NMIs vis-à-vis their principals may change over time, and in ways unanticipated at the moment of delegation. The British government believed that general competition authorities would be largely symbolic, to placate business interests; in practice, they became bodies exerting considerable powers (Wilks and Bartle, this volume). The ECJ has unexpectedly expanded its authority (and that of national judges) through its rulings (Tallberg, this volume). At times, the power of NMIs has differed sharply from formal institutional arrangements. The German Federal Cartel Office became a great deal more independent of elected politicians than warranted by its initial formal position. Establishing constitutional courts in Europe ultimately led to an important expansion in judicial, relative to legislative, power (Stone Sweet). 
Delegation has also influenced the power of private interests. It has offered new opportunities to challenge public decisions compared with previous state structures. Constitutional courts and courts reviewing administrative agencies through judicial review have allowed those who lose through the party political and central government process another opportunity to challenge decisions. Independent regulatory authorities have been more open to new entrants than governments, who engaged in closed relationships with national champion firms. ${ }^{40}$

NMIs have marked substantive policy decisions. General competition authorities and regulatory agencies have vigourously promoted liberalisation and the reduction of cross-subsidies. The European Commission and ECJ have aided increased European integration, economic liberalisation and the rights of individuals (including firms) against states. Courts have sometimes checked government secrecy, protected individual liberties and pushed forward policies across many fields. Independent central banks have promoted monetarist policies that give inflation a higher immediate priority than combating unemployment and seek to limit public expenditure. These are but a few examples of the effects of NMIs drawn from our case studies, for there is barely a policy domain unaffected by NMI action.

In analysing the direct impacts of NMIs, the formal powers of NMIs and controls for elected politicians offer a good starting point. The case studies also suggest that the wider political context affects the use of controls for example, the party structure and number of veto players and points. In countries such as Britain with few veto points and players, single party governments with majorities can more easily apply controls than in other countries (see, for example, Shapiro, this volume).

However, formal structures offer only limited explanation for the consequences of delegation. NMIs are not passive rather, they can be active, creative actors. They have learned how to exploit their powers in unexpected ways - the legal doctrines created by the ECJ and constitutional courts offer excellent cases (Shapiro, Stone Sweet and Tallberg, this volume). Informal norms grow up that may alter or subvert formal arrangements - for example, independence for the German Cartel Office. NMIs have sought to go beyond their formal roles and developed norms that may differ from their formal objectives and position (for instance, the German Federal Cartel Office and Bundesbank making independence from elected politicians a central norm or sectoral regulators setting themselves the promotion of fair and effective competition as their central objective see Wilks/Bartle, Döhler and Thatcher contributions, this volume).

\section{Feedback Effects}

The behaviour of NMIs modify the decision making, investments, and strategic interactions of other actors, which may feed back on principals and 
the NMIs themselves. The activities of courts or regulatory agencies have led interest groups to reorient their activities to them, in order to increase their own influence; in turn, the behaviour of those interest groups has provided new opportunities for NMIs to expand their influence. Earlier choices to delegate have also influenced later choices, for delegation is often a process rather than a one-off event and, moreover, one in which NMIs can be active agents. In the EU, the Commission and ECJ have been major players in treaty making processes, some of which have broadened their powers. At the same time, national governments have learned from previous experience: they excluded some new domains from the first 'pillar' of decision making; in other domains, where inter-governmental cooperation failed (for example, immigration or security), they delegated new powers to EU institutions (Jonas Tallberg, this volume). Similarly, the apparent success of regulatory agencies has led to a widening of their powers in countries such as Britain and France.

Explaining feedback effects requires attention to how the environment, especially the zone of discretion, structures the interactions between NMIs, their principals, and other actors. The ECJ's interpretations of the Treaty of Rome have produced powerful feedback effects, some of which have affected later Treaty amendments, partly because reversal requires unanimity among member states (Tallberg contribution, this volume). ${ }^{41}$ Another aspect is the presence of informal norms. The initial limited formal autonomy of the German Federal Cartel Office was expanded by strong informal norms; in turn, these hindered the creation of other regulatory bodies (Wilks/Bartle, Döhler, Thatcher, this volume). Feedback effects such as these were unanticipated by principals at the time of the initial delegation.

\section{Legitimacy and Accountability}

Delegation to NMIs poses difficulties for the traditional model of parliamentary accountability in Western Europe. Moreover, the legitimacy of NMIs affects their power and acceptance.

'Output legitimacy' is the current standard justification for NMIs. ${ }^{42}$ The superior performance of NMIs, relative to the result that would be likely if elected politicians were to perform the functions themselves, justifies their existence. Benefits include more 'efficient' policy making procedures and better policy outcomes, enhanced rights protection, lower inflation, and so on. In this view, delegation is portrayed as neutral and beneficial. Indeed, the legitimacy of NMIs is only at issue when agents are corrupted, or fail to deliver adequate levels of promised benefits. ${ }^{43}$

Yet the output model of legitimacy, because it ignores too much of political importance, does not offer a comprehensive response to many 
important legitimacy concerns. The model typically assumes ideological consensus on the role, function, and benefits to be accrued from delegation, whereas these points are contested by parties and groups. There are winners and losers from delegation to NMIs which form part of political struggles. The liberalisation of markets, part of the logic of creating independent regulatory authorities, have been the subject of vigorous partisan wrangling, precisely because some industries and interests will lose from liberalisation and the re-regulation that comes with it. There is intense controversy about how and whether to widen and deepen European political integration. Central banks may pursue low inflation, but their decisions may induce higher levels of unemployment.

A second model of legitimacy is procedural. It relies on the process of decision making by NMIs being better than the insular, often secret, deliberations of cabinets and executives. NMIs typically pursue clearer, more focused mandates than elected politicians, all the more so since delegation usually involves explicitly setting objectives for them. They are often obliged to give reasons for their decisions and to publish information. They are frequently more open than central governments to interested groups - for example, the European Commission is much more accessible compared to national bureaucracies, ${ }^{44}$ whilst in the utilities independent sectoral regulators have ended closed relationships of ministries and suppliers by creating elaborate consultation procedures. Legislatures have powers over NMIs, including rights over nominations, information and calling hearings, and have used them to publish valuable information and to put pressure on NMIs.

According to this view, procedural legitimacy is a fair and democratic substitute for electoral accountability, given the broader purposes of delegation. As NMIs have spread in Europe, these two models of legitimacy are increasingly combined: output legitimacy is bolstered by procedural legitimacy.

\section{CONCLUSIONS}

Delegation to Non-Majoritarian Institutions has reconfigured the architecture of the state and the EU, altered public policies, and raised issues of legitimacy and accountability. This volume explores some of the crucial questions at the very core of these politics. Who has delegated and why? What institutions have been established, for what purposes, and how great are their respective zones of discretion? How have NMIs actually governed and with what effects?

Although functional rationales can help us to answer some of these questions, purely functionalist analysis suffers from a number of major 
limitations, since it plays down the historically contingent, contested, and political sources and logics of delegation. ${ }^{45}$ Moreover, approaches that explain institutional design, without going further, miss much that is vital in the consequences of delegation. These limitations are well exposed by analysis of delegation in Western Europe, especially by cross-national comparison over time and across domains.

In response, this volume's contributors either supplement or replace purely functional accounts of delegation with more fine-grained or historically sensitive analyses of institutional choice. They investigate decisions to delegate in their contexts - country, time, and domain. They acknowledge constraints on the choices of principals - cognitive, normative, political, and constitutional - thus incorporating concern for policy learning and the spread of ideas, as well as the weight of inherited structures, norms, and experience. The volume shows that a broad range of outcomes are impossible to predict from the initial conditions of delegation, but are instead produced by the dynamics of interactions between NMIs and other multiple actors. The politics of delegation in Europe today calls for analyses going well beyond simple functional logics, involving how actors' interests are defined, policy is made and enforced, and the legitimacy of government is conceived.

\section{NOTES}

1. We have chosen to use the term institution as a synonym for a political body, organ, or organisation. In the standard vocabulary of social science institutionalism, institutions refer to the constitutive elements of the rule systems found in any human community. We use the terms, 'rules', 'law', and 'legal instruments' to refer to institutions in this second sense.

2. Good recent reviews of this literature include J. Huber and C. Shipan, 'The Costs of Control: Legislators, Agencies, and Transaction Costs', Legislative Studies Quarterly 25 (2000), pp.25-42; J. Bendor, A. Glazer and T. Hammond, 'Theories of Delegation', Annual Review of Political Science 4 (2001), pp.235-69.

3. E.g., W. Powell and P. DiMaggio (eds.), The New Institutionalism in Organizational Analysis (Chicago: University of Chicago Press 1991).

4. E.g., G. Majone, 'The Rise of the Regulatory State in Europe', West European Politics 17/3 (1994), pp.77-101; G. Majone, Regulating Europe (London: Routledge 1996).

5. E.g., M. Pollack, 'Delegation, Agency, and Agenda Setting in the European Community', International Organization 51/1 (1997), pp.99-134; M. Pollack, 'The Engines of Integration? Supranational Autonomy and Influence in the European Union', in W. Sandholtz and A. Stone Sweet (eds.), European Integration and Supranational Governance (Oxford: Oxford University Press 1998), pp.217-49.

6. In addition to the work of Pollack and Majone cited above, see J. Tallberg, 'Making States Comply: The European Commission, the European Court of Justice, and the Enforcement of the Internal Market' (Ph.D. diss., Lund University 1999); J. Tallberg, 'The Anatomy of Autonomy: An Institutional Account of Variation in Supranational Influence', Journal of Common Market Studies 38/5 (2000), pp.843-64, A. Stone Sweet and J. Caporaso, 'From Free Trade to Supranational Polity: The European Court and Integration', in Sandholtz and Stone Sweet (eds.), European Integration and Supranational Governance.

7. See T. Bergman, W. Müller and K. Strøm (eds.), Parliamentary Democracy and the Chain of Delegation, special issue of European Journal of Political Research 37 (2000). 
8. A. Stone Sweet, 'Judicialization and the Construction of Governance', Comparative Political Studies 31 (1999), p.147.

9. T. Moe, 'The New Economics of Organization', American Journal of Political Science 28 (1985), pp.739-77; D. Epstein and S. O'Halloran, Delegating Powers: A Transaction Cost Politics Approach to Policy Making under Separation of Powers (Cambridge: Cambridge University Press 1999), ch.3.

10. Huber and Shipan, 'The Costs of Control', p.41.

11. E.g., S. Balla, 'Administrative Procedures and Political Control of the Bureaucracy', American Political Science Review 92/3 (1998), pp.663-73.

12. Alternative ways of thinking about delegation do not necessarily embody alternative, or rival, explanations. For explanations to compete, they must be specified in a sufficiently clear causal form to be compared with one another, in light of empirical research and findings. It is possible that virtually identical hypotheses, or causal propositions, could be generated from quite different theoretical vocabularies and materials.

13. Epstein and O'Halloran, Delegating Powers, pp.24-5.

14. K. Bawn, 'Choosing Strategies to Control the Bureaucracy: Statutory Constraints, Oversight, and the Committee System', Journal of Law, Economics, and Organization 13 (1997), pp.101-26.

15. G. Majone, 'Two Logics of Delegation: Agency and Fiduciary Relations in EU Governance', European Union Politics 2/1 (2001), pp.103-22.

16. T. Moe, 'Political Institutions: The Neglected Side of the Story', Journal of Law, Economics, and Organisation 6 (1990), pp.213-53.

17. Majone, 'Two Logics of Delegation', p.113.

18. A. Stone Sweet, Governing with Judge: Constitutional Politics in Europe (Oxford: Oxford University Press 2000).

19. Stone Sweet and Caporaso, 'From Free Trade to Supranational Polity'.

20. E.g., Balla, 'Administrative Procedures'; T. Moe, 'An Assessment of the Positive Theory of "Congressional Dominance”, Legislative Studies Quarterly 12 (1987), pp.475-520.

21. J.W. Meyer and R.L. Jepperson, "The "Actors" of Modern Society: The Cultural Construction of Social Agency', Sociological Theory 18 (2000), pp.100-120; R.L. Jepperson, 'The Development and Application of Sociological Neoinstitutionalism', Robert Schuman Centre Working Paper 2001/5.

22. P. DiMaggio and W. Powell, 'The Iron Cage Revisited: Institutional Isomorphism and Collective Rationality', in W. Powell and P. DiMaggio (eds.), The New Institutionalism in Organizational Analysis (Chicago: University of Chicago Press 1991).

23. See also B. Levy and P. Spiller (eds.), Regulation, Institutions and Commitment (Cambridge: Cambridge University Press 1996).

24. In the field of European politics, exceptions include: Bergman et al., Parliamentary Democracy and the Chain of Delegation; J. Huber and A. Lupia, 'Cabinet Instability and Delegation in Parliamentary Democracies', American Journal of Political Science 45/1 (2001), pp.18-33; Stone Sweet, Governing with Judges.

25. Cf. P. Hall and R. Taylor, 'Political Science and the Three New Institutionalisms', Political Studies 44/4 (1996), pp.936-57; K. Thelen, 'Historical Institutionalism in Comparative Politics', The Annual Review of Political Science 1999 (Palo Alto: Annual Reviews 1999); E. Immergut, 'The Theoretical Core of the New Institutionalism', Politics and Society 25/1 (1998), pp.5-34.

26. For institutional isomorphism, see DiMaggio and Powell, 'The Iron Cage Revisited'; for policy transfer and learning, see reviews, notably D. Dolowitz and D. Marsh (1996), 'Who Learns What From Whom? A Review of the Policy Transfer Literature', Political Studies 44/2, pp.343-57; P.A. Hall, 'Policy Paradigms, Social Learning, and the State', Comparative Politics 25/3 (1993), pp.275-96; J.L. Campbell, 'Institutional Analysis and the Role of Ideas in Political Economy', Theory and Society 27/4 (1998), pp.377-409; R. Rose, Lessondrawing in Public Policy (London: Chatham House Publishers 1993).

27. Cf. H. Wolman, 'Understanding Cross-National Policy Transfers: The Case of Britain and the US', Governance 5/1 (1992), pp.27-45; for the example of telecommunications, see M. Thatcher, The Politics of Telecommunications (Oxford: Oxford University Press 1999). 
28. See also B. Doern and S. Wilks (eds.), Comparative Competition Policy: National Institutions in a Global Market (Oxford: Oxford University Press 1996); K. McNamera, The Currency of Ideas: Monetary Politics in the European Union (Ithaca: Cornell University Press 1998).

29. D. Coen and M. Thatcher (eds.), Regulating European Utilities, special issue of Current Politics and Economics of Europe 9/4 (2000).

30. Through a process that DiMaggio and Powell call 'normative isomorphism'.

31. Cf. S. Jacobs, Regulatory Governance: Improving the Basis for Sectoral Regulation (Paris: OECD 2000); J.L. Guesch and P. Spiller, Managing the Regulatory Process: Design, Concepts, Issues and the Latin American and Carribbean Story (World Bank: Washington 1999); B. Levy and P. Spiller, Regulation, Institutions and Commitment (Cambridge: Cambridge University Press 1996).

32. DiMaggio and Powell, 'The Iron Cage Revisited'.

33. C. Radaelli, 'Policy Transfer in the European Union', Governance 13/1 (2000), pp.25-43.

34. S. Berger and R. Dore (eds.), National Diversity and Global Capitalism (Ithaca: Cornell University Press 1996); V. Schmidt, 'Still Three Models of Capitalism? The Dynamics of Economic Adjustment in Britain, Germany and France', in R. Czada and S. Lütz (eds.), Die Politische Konstitution von Märkten (Opladen: Westdeutscher Verlag 2000); S.K. Vogel, Freer Markets, More Rules. Regulatory Reform in Advanced Industrial Countries (Ithaca: Cornell University Press 1996).

35. For a rational choice view of the effects of political context on delegation, see J. Huber, C. Shipan and M. Pfahler, 'Legislatures and Statutory Control of Bureaucracy', American Journal of Political Science 45/2 (2001), pp.330-45; J. Huber and C. Shipan, 'Legislators and Agencies: A Theoretical Reappraisal', Legislative Studies Quarterly 25 (2000), pp.25-52.

36. Cf. A. Héritier, C. Knill and S. Mingers, Ringing the Changes (Berlin: De Gruyter 1996); for electricity where no sectoral regulator was created in contrast to other EU countries, see B. Eberlein, 'Institutional Change and Continuity in German Infrastructure Management: The Case of Electricity Reform', German Politics 9/3 (2000), pp.81-104.

37. Cf. Wolman, 'Understanding Cross National Policy Transfers'; Thatcher, The Politics of Telecommunications.

38. See Huber et al., 'Legislatures and Statutory Control of Bureaucracy'; and Huber and Shipan, 'Legislators and Agencies'.

39. Such losses arise from agency 'slippage' (agents following their own preferences which diverge from those of its principal(s)) and 'shirking' (institutional incentives causing the agent to behave contrary to the wishes of its principal(s)). See M. McCubbins and T. Schwartz, 'Congressional Oversight Overlooked: Police Patrols versus Fire Alarms', American Journal of Political Science 28/1 (1984), pp.165-79; McCubbins et al., 'Administrative Procedures'; T. Moe, 'An Assessment of the Positive Theory of Congressional Dominance', Legislative Studies Quarterly 12/4 (1987), pp.475-520.

40. Thatcher, The Politics of Telecommunications; J. Hayward (ed.), Industrial Enterprise and European Integration. From National to Internationalized Champions: Firms and Governments in the West European Economy (Oxford: Oxford University Press 1995).

41. Explored at length in Stone Sweet, Governing with Judges, ch. 6.

42. Cf. Levy and Spiller, Regulation, Institutions and Commitment; Majone, Regulating Europe.

43. G. Majone, 'The Crisis of Community Credibility', Journal of Common Market Studies 38/2 (2000), pp.273-302.

44. S. Mazey and J. Richardson (eds.), Lobbying in the European Community (Oxford: Oxford University Press 1993).

45. Cf. Moe, 'Political Institutions'. 